\title{
Years of Apprenticeship
}

\author{
David Pierce \\ York, England
}

Copyright (c) 2012 by David Pierce. This text may be archived and redistributed both in electronic form and in hard copy, provided that the author and journal are properly cited and no fee is charged for access.

David Pierce's most recent titles include Reading Joyce (Pearson Longman, 2008), Joyce and Company (Continuum, 2006), and Light, Freedom and Song: A Cultural History of Modern Irish Writing (Yale University Press, 2005). Here is an extract from a memoir he has just completed entitled The Long Apprenticeship: A Writer's Memoir (Matador, 2012).

If in 1971 you wanted to pursue almost any topic in Irish Studies, you were heading for trouble. August 1971 marked the beginning of Internment in Northern Ireland and an upsurge in violence across the region. Thereafter the Troubles only became more intense, the mood more sombre, and for those bent on quiet reading it grew increasingly difficult to keep politics at a distance. This was the background to those early years of my research into Irish writing. As I drove down into Irish history, there was a constant interruption from the present. Indeed, it was quite a struggle to identify what was background and what was foreground. The political situation was providing a resurgence in the colonial encounter between Britain and Ireland, but my research concerned quieter, more literary questions, at first into writers from County Clare and the province of Munster but then into the relation between fiction and society beginning in the first half of the nineteenth century with Maria Edgeworth and William Carleton. How would I connect what was happening in the present with what happened in the past, or should I have addressed the dilemma in a much more direct fashion and undertaken work on contemporary writers from
Ulster? Perhaps I should have applied what I had learnt the previous year about the Spanish labyrinth to the Irish situation, for in many ways that is what I was absorbing at this time, that there was an Irish labyrinth which embraced history and the present, politics and literature.

This is what can happen when politics is so intrusive, it threatens to monopolise all the space. Writers in the North took the lead in distinguishing their writing from what was happening on the streets. It was their way of responding to events and marked a refusal to retreat behind the traditional lines of their tribe as it were. Writing should act not as the expression of tribal beliefs or prejudices but as a gesture toward utopia, a world free from sectarianism. There was a certain irony about such a response and yet it was not without a history. Yeats, at the height of the Irish Civil War in 1922-3, pacing the battlements at the top of his Tower at Ballylee on the ClareGalway border, reflected on the little room that was Ireland: brothers, dressed in one kind of uniform, killing brothers, dressed in another. With its play on Killaloe, a monastic settlement in County Clare, 'Killallwho' is how Joyce the exile puts it in Finnegans Wake, 
a book that bears the scars of the Civil War, the period when he began his last great work. Kill all who are different, or, given that we're referring to a civil war or civil strife, kill all who are the same as you, farmers, labourers, members of the working class, or from the same family or who have the same surnames. Only rarely it seems to me have writers taken to the barricades as Liberty does in the famous painting by Delacroix, leading the people. In times of heightened political agitation, as was the case in Northern Ireland in the 1970s, writers did well to carry any sort of torch. That seems to be the political lesson to have come out of those bleak years.

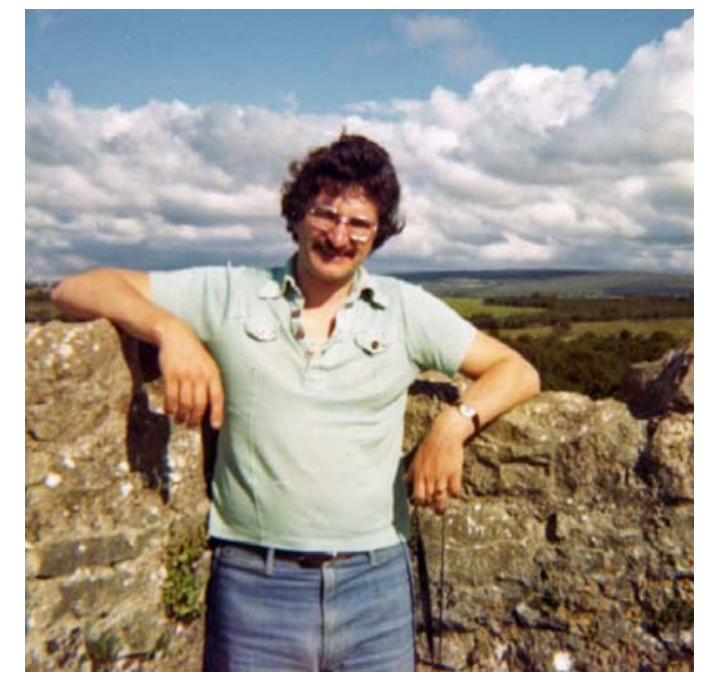

At the top of Yeats's tower at Ballylee on the borders of County Clare and County Galway. Taken around 1977 on a day when there was a break in the clouds. The view of the surrounding countryside today is much as it was in the 1920s when Yeats lived here.

I was no different to anyone else. I was observing a tragic story unfolding and I felt I should do something about it. But how would a cross-channel perspective help when lines were so sharply drawn? I continued with my reading, all the time agitated about something else. Left-wing groups in Britain tended to be pro-republican and some of them interpreted what was happening in the North as parallel to Vietnam in the 1960s. If the IRA could defeat the British Army then this would have repercussions internationally. But that would mean backing a movement whose social policies at that time had little to recommend them. And, besides, what would you do with the million Protestants who didn't want to live in a united Ireland? In retrospect, the early 1970s was a period that had 'cul-de-sac' written all over it. The hopes of the Civil Rights movement in 1967 had turned sour and had forced people back into their traditional allegiances. It would take a generation, and another generation, to begin to rediscover politics anew. The Left in Britain were also found wanting. As the early 1970s confirmed, interest in Irish politics has for the most part only ever been fitful, half-hearted, instrumental, or romantic. I kept up my research at the University of Lancaster, extending my reading and auditing the MA in modern literature.

When Williams published The English Novel from Dickens to Lawrence in 1970, it followed closely Leavis's The Great Tradition: George Eliot, Henry James, Joseph Conrad (1948). Williams selects a different set of authors and enlarges the historical frame, but he, too, like Leavis, is interested in a cultural tradition and in the idea of succession and continuity. The two accounts belong together as striking examples of critical compression and distillation, each critic conscious of how a novelist comes to represent a particular line or shift in the culture. Their approaches differ. Williams sought to extend the work of Leavis to allow for materialist or social contexts, whereas Leavis has in his sights the upholding of a distinctive set of values in writing. When I was at work on Irish writers there was very little by way of an equivalent body of criticism on which to draw. As was only proper, modern Irish history tended to be dominated by political history or church history. There were the beginnings of an interest in economic history, particularly around the Famine of the 1840s, and in social history. Literary history was distinguished by its attention to single authors. Irish cultural history was still in its infancy.

I should have begun with a conventional survey of the field and addressed the issue of my potential contribution, but I was devoting all my time to reading round the topic and not enough to reading through the topic. With the Anglo-Irish novelist Maria Edgeworth I became interested in her position vis-à-vis Irish writing compared with Jane Austen and her influence on English writing. I was intrigued by Edgeworth's sharply articulated political themes versus Austen's concern with manners and less overt or buried political themes. With 
William Carleton, the pre-Famine writer who came from a family of small farmers in Ulster, I was drawn into a comparison with Dickens, and always the Irish writer came off the worse. How to integrate material became a concern for me. There was social commentary, gothic elements, bits and pieces from an oral tradition, plot contrivances, larger than life characters, representative types, clichéd romantic scenes, authorial comment - how could I see a way of handling all this or grounding it? Moreover, the Irish novelist was always looking over his or her shoulder at the 'sister kingdom' whereas the English novelist just got on with the task in hand. In the wake of the Act of Union in 1801, the issue of Irish identity did not subside but intensified. For a young researcher in the early 1970s I needed a body of critical work to take me forward, and I also needed not always to see limitations as limitations but to understand them in a wider, more enabling framework.

In February 1972 I spent a fortnight in Belfast with a colleague and friend I had taught with at the British Institute in Madrid. Shivaun, who came from a large Catholic family, would frequently confess she was a rebel without a cause, but when she returned home in 1971 she discovered a cause. A week after Bloody Sunday we took part in a march in Newry to protest against those murders in Derry. When we arrived we parked in the centre of town and were given tissues or face-cloths to protect us against teargas and little cards in the shape of a coffin emblazoned with the number 13 . Trouble was expected, but the size of the crowd made that unlikely. We were buzzed by an army helicopter and someone in a suitably imperious voice informed us that the march was illegal and that we should make our way home. The march proceeded peacefully, though [no one was certain there wouldn't be a repetition of the previous week. It was dark when we came to retrieve the car, by which time the centre of Newry had been cordoned off. Crouching in every doorway was a soldier with blackened face and automatic rifle at the ready.

Belfast at that time was a war-torn city, or perhaps it's better to say it was a city turned in on itself. One evening one of Shivaun's sisters took us to the Markets area in Belfast to visit a friend who lived in a terraced street at the end of which stood an obtrusive and smelly gasometer, glowering. The house was about the size of my about the size of my Sussex childhood home with an outside toilet. The family, minus the father, were all there in the front room, and we spoke about the situation, how the Army would regularly enter the area and 'lift' people, and how Catholics in the North had been abandoned by the Dublin Government and by people living south of the border. The house abutted onto the pavement, so you could hear every passing murmur and agitated footstep outside. It was apparent that these people enjoyed almost no protection from their immediate environment or from the wider social and political forces at work. All of us then made our way to an upstairs social club nearby, which was full of women but no men for they had all been 'lifted' in the autumn as part of the Internment process. Here I thought was Yeats's little room, except that whereas the poet imagined it full of hate what I encountered was a warm welcome for someone who could protest his family hailed from County Clare but who spoke with an English accent.

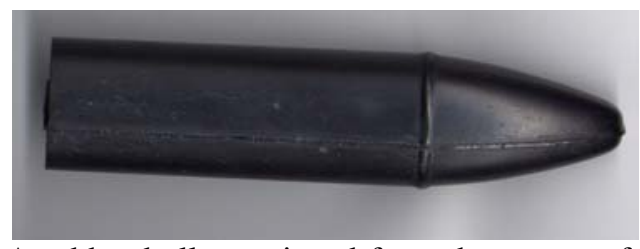

A rubber bullet retrieved from the streets of Belfast in the weeks around Bloody Sunday, 1972. There are no markings on it, so it must have fallen out of its container without being fired. From author's collection.

Belfast at that time was a war-torn city, or perhaps it's better to say it was a city turned in on itself. One evening one of Shivaun's sisters took us to the Markets area in Belfast to visit a friend who lived in a terraced street at the end of which stood an obtrusive and smelly gasometer, glowering. The house was about the size of my Sussex childhood home with an outside toilet. The family, minus the father, were all there in the front room, and we spoke about the situation, how the Army would regularly enter the area and 'lift' people, and how Catholics in the North had been abandoned by the Dublin Government and by people living south of the border. The house abutted onto the pavement, so you could hear every passing murmur and agitated footstep outside. It was apparent that these people enjoyed almost no protection from their immediate environment or from the wider 
social and political forces at work. All of us then made our way to an upstairs social club nearby, which was full of women but no men for they had all been 'lifted' in the autumn as part of the Internment process. Here I thought was Yeats's little room, except that whereas the poet imagined it full of hate what I encountered was a warm welcome for someone who could protest his family hailed from County Clare but who spoke with an English accent.

Let me come at this again. If you were engaged on an apprenticeship in Irish Studies in the early 1970s, you could do worse than spending time in Belfast. As you stepped outside to go for a drink in the evening, you would catch the sound of gun-shots coming from some part of the city. Returning indoors you would phone the security services to ascertain the location, and then drive to a different part of the city. You never sat against the outside wall of a pub or restaurant and you found comfort in bars which had a wire-mesh round the outside of the building. That much was certain, but one evening listening to a group playing traditional Irish music we got into conversation with them only to discover something unexpected. Shivaun mentioned she was teaching in a Catholic secondary school in Downpatrick, and the conversation ended awkwardly when one of the musicians retorted: 'You only have to teach them, we have to fight them.' That was a bit of shock, for Shivaun and I considered we had a fairly sure touch when it came to distinguishing Catholics from Protestants, but we then realised afterward that traditional music in the North cuts across tribal boundaries, or, rather, it could cut across such boundaries, for this was a Protestant group playing traditional music.

There were prejudices, then, on all sides, and communities, whether they wanted it or not, were in the process of returning to their own. At that time Shivaun's family lived in a mixed street, and in a house opposite there was an elderly Protestant woman I enjoyed talking to. She would refer to her son Earl (or he might have been Errol), who lived away, as a 'Markist'. This took me some time to work out and I didn't have the heart to ask her. No, he wasn't employed at Marks and Spencer but was in fact a Marxist. On another occasion we drove to visit a friend who lived on a mixed estate on the outskirts of the city. On approaching the estate we glimpsed ahead of us one of the many paramilitary checkpoints which had sprung up across the North, this time manned by a Protestant group. 'Have you any rosary beads on you?' Shivaun's sister turned to me anxiously before we pulled up. 'If you have, throw them out of the window immediately or hide them.'

Repeatedly, throughout this strange period, a sense of one's common humanity was being trampled on or squeezed. Under pressure, indeed more so under pressure, fellow-feeling was something you wanted to hang onto. People you met gave the impression they knew something they shouldn't know or had seen something they shouldn't have seen. In Shivaun's family when the death of a British soldier was announced on the radio, her parents stopped what they were doing, bowed their heads, and said a prayer for the soldier and his family. On the landing above the stairs hung a framed portrait of Robert Emmet, the leader of a failed rising in 1802 against the British connection, and Shivaun's elderly father would speak of the 'Imperial Parliament', meaning Westminster. But their political allegiance refused to countenance killing people. For them no amount of injustice could justify that. Their attitude wasn't a form of stoicism but more like tolerance learnt from the crucible of a troubled history, and it issued from a more noble tradition which understood how a wound took time to heal, for at some point the talking would have to begin again. I admired this attitude, especially as my pro-nationalist and pro-republican feelings were at their most intense. It cautioned me to think again about what I was coming increasingly to recognise in the light of my experience in Spain as the Irish labyrinth.

I understood why Shivaun in Spain had felt she was a rebel without a cause, for, like many of us who went to university in the 1960s as first generation, identity was linked too closely to the issue of one's family and class or religious background, from which we were hoping to escape. Identity was not something you wanted necessarily to wear as a label pinned to your lapel, but that was what was happening in the North. You were being forced back, co-opted, enlisted. 'Oh, so you went to such and such a school. You must be a 
Catholic.' 'Oh, you worked in the shipyards or in this particular hospital or brewery. You must be a Protestant.' I'm sure it was true for others as it was for me that identity veered too close to claustrophobia for comfort. In spite of leftwing and republican sympathies, I was not a fully signed-up member of anything. At the same time I was not a rebel without a cause. As I began to rethink the nature of identity and engagement in an era increasingly defined as post-Civil Rights and post-1968, I felt things on hold.

Little by little the months I spent in Ireland during the spring of 1972 changed me. When I arrived at my aunt's cottage in County Clare after the unsettling few weeks in Belfast, I found it difficult to express my feelings on the North. It was like being in a different country, which, of course, given the border, it, legally, was. I had heard the cock crowing again in the North, but nothing could wake the sleepy West from its slumbers. As a child, I rather took to the slow pace of life west of the River Shannon, but now that seemed like an obstacle blocking the road to rationality and the future. Two generations before, in the aftermath of the Easter Rising, the electorate in County Clare voted in Eamon de Valera in a famous landslide election, and throughout the nineteenth century the so-called Banner County could be relied on to rally their banners behind nationalist candidates and land reformers. Indeed, in 1831, a celebrated, advanced social experiment took place at Ralahine when a co-operative society was established on the estate of John Vandeleur in Newmarket-on-Fergus. I had been through something intense and imagined it might be of interest to share that with those who lived in the same country south of the border, but the traveller to foreign lands was in for an even greater shock on his return.

Addressed to a Miss E.A Hapgood, Woodstock, Vermont, U.S.A., the following Edwardian postcard was sent from Ireland by an American visitor in August 1900. It tells of 'visiting the tombs of our ancestors but thus far do not find many of the aforementioned tombs', and how the following day they will take the boat down the Shannon from Athlone to Killaloe, and then by train to Limerick, and then on to Cork and Queenstown.

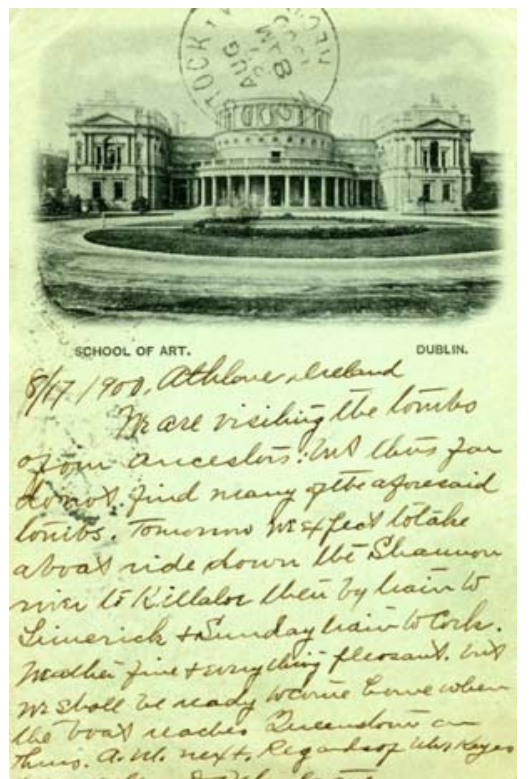

As I read this century-old postcard of a pleasant trip through the heart of the province of Munster, I am reminded that writing a memoir is also a journey into the past, and can involve visiting the tombs of ancestors. Equally, whether we are natives, foreigners, tourists, or blessed with Irish roots, writing about Ireland not infrequently has its origins in actual journeys we undertake, and it shapes itself, therefore, as a travel narrative, where we are at once outside and inside something.

One evening, some elderly neighbours, on their way home from a drinking session in Liscannor, arrived at my aunt's cottage, and, propped up against the dresser, began singing together 'The West's Asleep', a song written in the 1840s for The Nation by Thomas Davis. Gaining confidence from each other, they moved steadily toward the final stanza when they eventually found the lift of the 'Hurrah!' they were waiting for:

And if, when all a vigil keep,

The West's asleep! the West's asleep!

Alas! and well may Erin weep

That Connacht lies in slumber deep.

But, hark! a voice like thunder spake,

'The West's awake! the West's awake!'

'Sing oh! hurrah! let England quake,

We'll watch till death for Erin's sake!'

We all cheered the successful execution of what is quite a difficult, ruminative song to sing. 'Good man, Peter! Fair play to you, Timmy! And you, Jimmy! You've still got it in you.' I should have responded more enthusias- 
tically, but, somewhere deep inside, out of reach of my conscious mind, I was hearing not the strains of an heroic past, merely its echo. I was in an agricultural labourer's cottage, cottages which had been built after the Land War in the 1880s in part to defuse the continuing unrest in the countryside and to separate out the nationalist from the social question, and I was observing some of the locals giving voice to a rallying cry against the old enemy, and this at a time when the British Army was intimidating and interning Catholics in the North and the singers themselves largely indifferent to, or ignorant of, their plight. There was something depressingly ironic about all that. The armoured vehicles I had witnessed swaggering almost through the Victorian streets of Belfast only weeks before showed little sign the enemy was quaking. On the contrary, 'well may Erin weep,' I heard myself repeating.

The songs about the West, which I, too, throughout my teenage years enjoyed singing, were defiant, and spoke of revenge and resentment among the families of hill-siders, of making way for the bold Fenian men, and of taking the fight to the Saxon stranger. Several people independently told me, with the Black and Tans in mind, the old blood coursing again through their veins, how they would resist any future invasion if one were to be attempted. But this kind of talk or bravado was as far as the connection with the present, or the contemporary relevance of the songs, would go or allow. In the second half of the twentieth century, Clare people, the gentlest of people, had been increasingly confined to the role of passive spectators rather than active participants in events. I would have been surprised if any of those I knew had journeyed to Dublin to burn down the British Embassy in the weeks following the shooting dead of the thirteen people in Derry that year. In some ways that's not so remarkable. Each year, the Tolpuddle Martyrs are venerated for their role in the beginnings of trade unionism in Britain, but the pretty Dorset village today, with its picture-postcard, thatched cottages, betrays almost no sign of wanting to overthrow the status quo.

Repeatedly, then, news bulletins on Irish television carried reports of violence from the North, but there was a certain ambivalence in the South. One or two politicians advocated some sort of military intervention or covert supply of weapons to the IRA. At the other extreme, some (possibly the majority) hoped it would all go away. One of my close friends in the Irish Labour Party considered - perhaps not unwisely in retrospect - that you shouldn't have a policy on the North. On a prominent wall on the road to Ennistymon on the outskirts of Ennis, someone had scrawled the slogan 'Up the IRA'. It was dismissed at the time as the work of corner boys and not a reflection of those who were serious about politics, and in time it faded. Through it all, I was beginning to discern, firstly, how the chains with a radical tradition in the past had been broken or were no longer visible as such, and, secondly, how complex was the Irish labyrinth when you were in the middle of it.

Most days, the clouds queued up and the winds from the Atlantic drove in without respite, but nothing could shake the claustrophobia which was all around me. Indeed, few people showed any real interest in learning about what a city is like when the bombs are exploding. It felt as though I was speaking out of turn and being accused of something, of whipping up emotions for example, or, worse, of being an agitator. 'Let the cock crow' seemed to be the attitude. 'We have our own lives to lead down here, and, besides, we're now looking to join the Common Market. The North will only bring trouble to this island.' One of my favourite uncles, who belonged to the period of ancient myth and showed little appreciation of the thing we call history, would tell me with utter conviction in his voice: 'Those troubles will only end when they reach Loop Head and drown in the sea'.

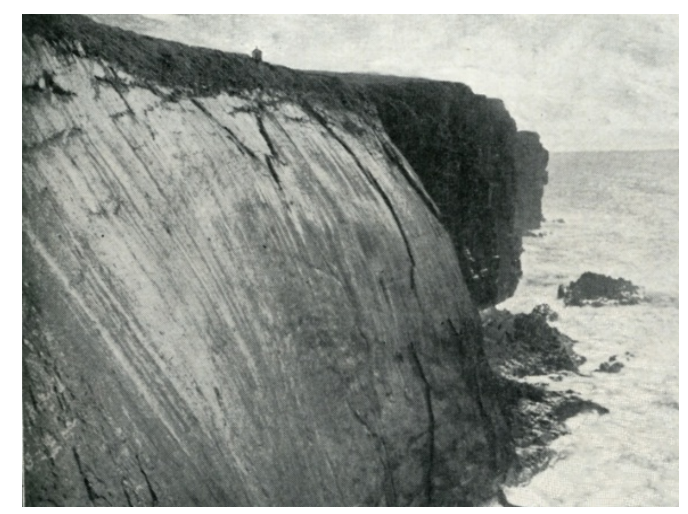

The 'unrivalled headland' of Loop Head on the south-west tip of County Clare. From John L. Stoddard's Lectures (1902). Ceann Léime in Irish means Leap Head. 
I was reminded again of the frog with the amputated leg wriggling in the palm of my hand, which as a child I had brought in from the newly-mown meadow in Caherbarna to show to our elderly neighbour, Denny Guerin, and how he rounded on me: 'Take that thing out of the house, and leave it where you found it.' Without my realising it, perhaps it was the case that everyone was trying to protect me from myself, calling me back to the protection offered by the family, tribe, or parish. Could history, I began to ask myself, repair itself like nature without too much outside intervention or interference, and was history in the North now taking its natural, if bloody, course? Leave it where you found it.

In retrospect, I now see that what informed my thinking throughout these years was an attempt to redraw the map of literature and history to take account of the periphery and the margins. Today, we might define such an approach under the general heading 'localism', but it would be misleading to conclude that was my direction of travel. A dominant ideology can make use of localism to advance its cause and to forward its own ends. It suited a Whig-influenced historian such as George Cornewall Lewis in 1836 to call his study of agrarian agitation in the eighteenth century $O n$ Local Disturbances in Ireland. For, as every Head Teacher knows, it is convenient to claim that only a handful of unruly pupils are disrupting the work of the school as a whole. Not unlike Sean O'Faolain and Kate O'Brien in their novels in the 1930s, what I sought was some kind of shift in how the regional and the local were conceived. Occasionally, when reading Ascendancy writers such as Yeats and Lady Gregory on rural Ireland, I felt a certain resentment that they claimed ownership over the people I came from, treating them as examples in a larger argument against English influence in Ireland. At the time I found it difficult to articulate, but what I sought was the overthrow of such models of thinking in favour of a world where everyone could speak for themselves.

I could have been undone by so much youthful confusion and contradiction and talk of Irish identity, but, ironically, it's important to witness things close up to acquire some kind of perspective. Equally, I had observed enough to convince me that it would take me years to make any sensible contribution to Irish Studies. I felt that was part of my apprenticeship as a researcher, and I don't regret these early years not having a neatly defined programme nor being allowed by my tutor to find my own feet. Some kinds of encounters or passages of history take decades before they are absorbed by the mind or bear fruit.

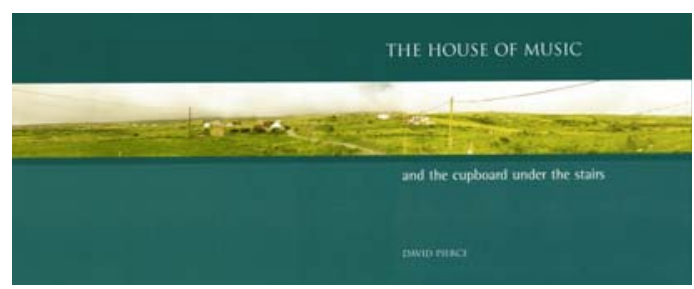

In 2000, I had privately printed a book about my family and incorporated into the cover a view of Caherbarna in Liscannor, the village where my grandmother lived and where theclouds would gather at any hour of the day or night above the Cliffs of Moher. This is where I took my first steps in June 1948.

People I come into contact with sometimes assume because I don't wear my heart on my sleeve that I'm not political, but all my training has been in the art of discerning a way through to a different kind of politics, a politics of hope which is impatient with the present and with much of what passes for politics. You don't always have to shout to be heard. Many people in Britain and elsewhere seem content to accept the view, repeated ad nauseam by my tutor when I was doing 'A' Level British Constitution in 1966, that 'politics is the art of the possible', but to my mind the 'possible' is never a given but always in need of unpacking or deconstructing.

A politics of hope not infrequently throws things up in the air and forces its adherents to reconsider past, present and future. In May 1986, a month after Chernobyl, at the invitation of Dorothea Siegmund-Schultze, I gave a paper at an Irish conference in Halle in the German Democratic Republic (GDR), and I happened to quote in passing a phrase about aesthetics being the ethics of the future. Two of the participants found this a genuinely insightful observation, and they joined me afterward in a small group discussion. They would have been active members of the Communist Party whose thinking would have followed fairly conventional lines of inquiry. 
Suddenly, there was something new in their lives, a comment that intrigued them and I could see them working with it.

I was more interested in why there was no premium on beauty in the culture or their lives, in why, for example, William Morris was missing from their pantheon of the great and the good. Halle, which was Handel's birth-place, had not been destroyed in the War, and it would have been an attractive city if the facades of the buildings had been cleaned up and if the Coketown-like pollution issuing from the huge chemical works on the edge of the city had been choked off. 'Never mind about the future,' I said. 'What about the present?' 'Oh, we don't have the money for that kind of thing. We have a team of six workers currently attending to buildings in Berlin. Halle is next in line.' In the GDR, beauty belonged not to Marx's economic base but to its ideological super-structure, determined but not determining, closer to a facade than to an informing structure. To my two listeners, the subsequent question I posed was a simple one, 'Do you not think Morris has something to contribute to our continuing understanding of Marx?' After the fall of the Berlin Wall in 1989, the question was put on hold but to my mind it hasn't gone away.

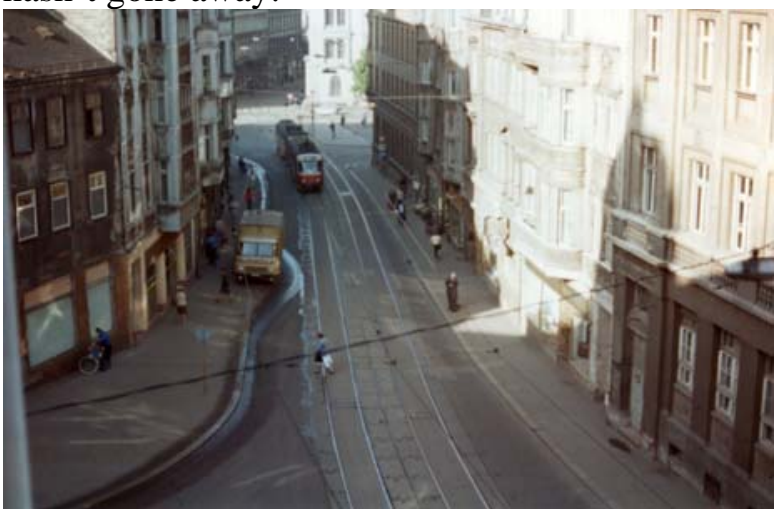

A photo of one of the main roads in the centre of Halle, taken from my hotel window in May 1986. Oblivious of the light and shade, a beautiful, Czechbuilt tram moves quietly through a street largely empty of pedestrians, awakening a certain eeriness about the scene.

I took the following photograph of the notice 'Unser Wettbewerb' (our competition) in the village of Memleben in Saxony-Anhalt in May 1986. It shows the results of which groups were doing well in the various collectives in the local vegetable and seed-growing plant. At a conference dinner in Halle hosted by leading local dignitaries, we were all surprised by their candid admission concerning the failures of collectivi- sation. If we are shocked by such valuing of work, perhaps we should consider why that is the case.

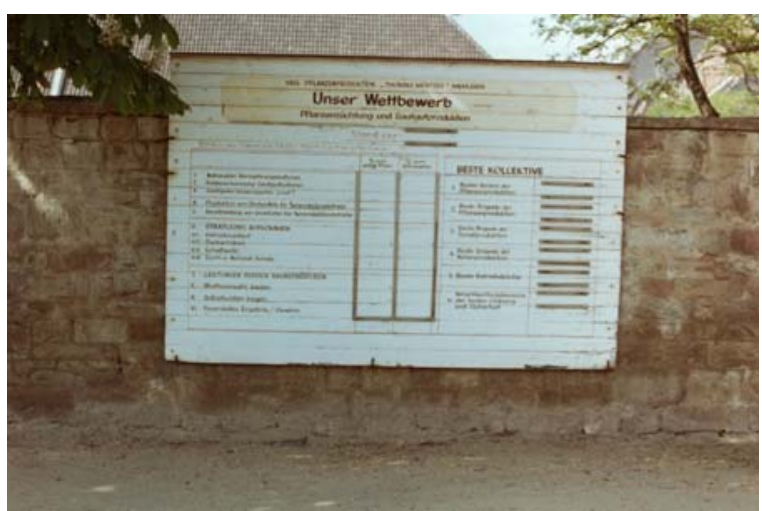

When I travelled to the GDR for conferences in the 1980s, I would rely on a politics of hope to see me through. I realised how difficult it was for academics there to get hold of material, so I would bring over with me a bag filled with modern literature books. I was told about a group of lecturers at the Humboldt University in Berlin who hatched a plan to buy a photocopier in West Berlin, undertake a one-day course while there in repairing the machine, then trundle it back through the border crossing. That way they could copy chapters of books borrowed from the UK's Inter-Library Loan service at Boston Spa. It struck me as a fairly hopeless venture, for photocopiers at that time kept breaking down, sometimes on a daily basis, and I came to see it as further proof, even though it was only a tiny example, that the system as a whole was at breaking point. However, I had to admire the resourcefulness of academics in tight circumstances, and I might have done the same. I could just imagine them returning the machine for its annual service across Check Point Charlie and reporting back on the conversation with East German officials (some of whom had once subjected me to a menacing, full-scale search and interrogation at Friedrichstrasse).

My visits to the GDR began with an invitation from Horst Höhne, who was a leading academic and critic. He wrote extensively on Shelley and Keats, and invited me on several occasions to what was then known as the Wilhelm-PieckUniversiteit in Rostock. I stayed in his large, well-proportioned, first-floor flat, which had been built in the 1950s, when hope for a better future was in the air. As soon as I was ushered in out of the cold and the damp of an autumn evening, I recall noticing the wooden parquet flooring and the secondary glazing. One day he 
showed me a folio edition of Luther's Bible, dating from the 1530s, which had come down through the family of his wife, Barbara. After placing it on the dining table beside the lightfilled window, he began reading verses from the Sermon on the Mount. Somehow, he made Luther's German, with its use of Saxon dialect, sound like its linguistic cousin, English.

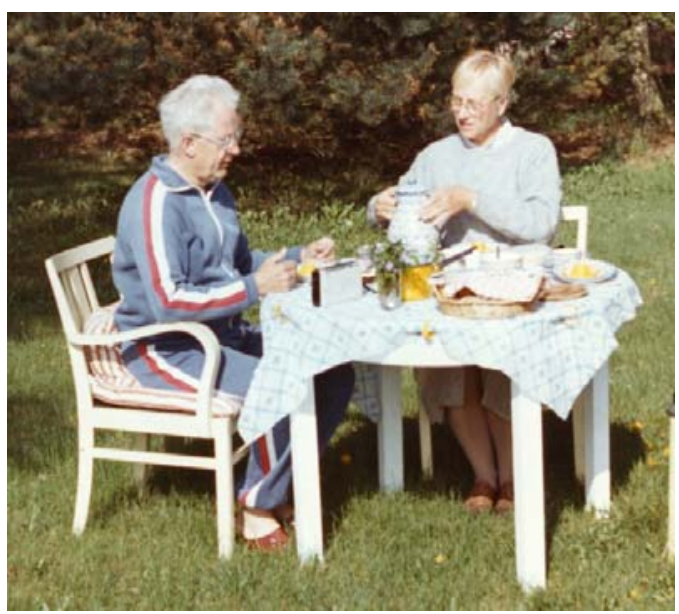

Horst and Barbara Höhne having breakfast in the garden of their second home in the country outside Rostock. Horst's first conference I attended was held on the Baltic coast in Ahrenshoop in October 1984. It was entitled 'Challenge of the Century: Third Symposium on Twentieth-Century English and American Poetry in its International Perspective', and among those who attended were Angus Calder and Michael S. Harper. I gave a talk on 'The Social Eye/I: A Critical Engagement with Recent English Poetry’.

On another occasion, we were surrounded by a group of middle-aged academics from all over what used to be called the 'socialist countries' of Eastern Europe. They were discussing the past and the difficulties of the present, when, suddenly, Horst produced the sword that accompanied him as a boy of sixteen when he rode into battle on horseback against the Russian Army. He told me afterward how he had participated in one of Hitler's last, desperate measures towards the end of the War, and how his unit had encountered a Panzer division in retreat, but nothing the tank commanders said would prevent the boys from fighting in the Fuhrer's cause. When he was captured, he was surprised to discover that the Russian peasantry farmed the land, for they had been told the enemy were just primitive people, without agriculture. He was then marched back into Germany and passed through his home village, where he caught sight of his mother for the last time. After the War came another momentous change in his life when he joined the Communist Party.

My first introduction to Horst, which took place at York Station, was, appropriately, like something out of a John le Carré novel. For at least thirty minutes we paced up and down onone of the platforms under the vaulted, Victorian canopy, suspiciously eyeing each other, before I approached a person in a pale blue suit to ascertain if he was the East German Professor I was supposed to be meeting. Thereafter, I got to know him well, and his knowledge of English literature and western culture rarely failed to impress me. When commenting on Keats's line 'A thing of beauty is a joy for ever', he focussed on the one word 'thing', a word that to him was, really, the German word Ding, and then proceeded to invoke Luther's project in using plain language and, more widely, the line in German philosophical thinking from Hegel to Marx on externalisation and reification. In that one move, taking his cue from the cockney poet, Keats, he launched into a discussion about aesthetics and politics from a historical and materialist perspective, at the same time reminding his audience of the positive gloss that could be given to the 'thinginess' of things. Horst was a compelling speaker and unbelievably responsive to the tenderness in Keats's later correspondence, but, with my long-standing interest in words rather than things, I found myself drifting off. At the outset, Keats must have had the opening line to Endymion (1818), for you couldn't imagine him beginning with 'An item of beauty' or 'Something that is beautiful'. That tentative phase in his poetic career was behind him.

After 1989, we corresponded occasionally, but we never managed to meet up again. I would try and encourage him to compile a memoir of his life, for that would have been quite something. Our paths seemed to cross at the wrong time, for in the 1980s I was increasingly looking to hope and the future and Horst to making history in a more practical way. Coming from Thatcher's Britain, where the very idea of society had been called into question, all his talk about 'our hospital' and 'our school' and even 'our working-class housing estates' would surprise me as he took me on a tour of the Baltic capital in his noisy, three-gear Trabant, a car which, he delighted in 
informing me, never broke down.

Horst's insistence on 'our' provoked several responses inside me. I didn't find it reassuring or indeed a sign of hope, but, rather, cloying and premature. After all, flying by night across the dark skies of East Germany and then hittinga wall of light on coming into land in West Berlin was a reminder that socialism had some way to go to compete with the dynamism of capitalism, and it looked increasingly unlikely that it would be given the chance to continue in such a form in the 'socialist countries'. When the Wall did come down in 1989, just over forty years after the country's birth as a democratic republic, there was surprisingly little resistance. It was as if the older generation had been unable to pass on the flame to the next. Of course, if capitalism fails in the century to come or loses its appeal, people might revert to development along socialist lines.

I think the appearance of the sword and Horst's story about the cavalry unit was designed to turn the discussion away from the awful past which had engulfed that whole generation. Anything which he couldn't pull along from the past, which he couldn't integrate or in some way own, Horst was given to dismissing. The sword had become an empty signifier, poetry a thing of beauty. However, joining the Left Opposition in western Europe after 1989 was, I suspect, temperamentally a step too far. I never did discover how he came to lose the sight in one eye.

Returning to the early 1970s, this was a particularly bleak period across the world. Along with many others I was deeply affected by the CIA-backed coup against Salvador Allende in September 1973, a coup which was the quickest in modern history and in many ways the most poignant. But today it is also apparent that the tender songs of the Chilean folk-singer, Victor Jara, for example, will outlast those who attempted to silence him. As his signature song, 'Manifiesto', reminds us, he didn't sing for singing's sake but to be heard. His guitarra trabajadora, his worker's guitar, carried in its heart a message, and part of that message is now from the other side of the grave, and even more poignant therefore. Appropriately, the phrase that stands over his grave in the cemetery in Santiago is 'Hasta la victoria', towards victory. Chile and Ireland. Loss and struggle. As I learnt from my Irish grandmother: 'Never give in. Never give up.' Siempre será canción nueva. Always there will be a new song, a reference both to the Chilean folk-song movement associated with Allende and Unida Popular or the Popular Unity Party, and also, more generally, to the idea of rebirth in struggle. The accent on siempre reverberates long after the song has finished, but perhaps only those whose lives are surrounded by suffering can vouch for the truth of that final line.

I often return in my mind to the 1970s and 1980s and to what those years taught me about the movement of history and about the importance not so much of 'the pleasures of hope' in Thomas Campbell's comforting phrase from the Romantic period and 'the boundless fields of rapture yet to be' as of never abandoning hope. When defeat threatens, regroup and bide your time, and give the next generation something to do. Three decades later, the theme of loss and struggle surfaced as an extended argument in Light, Freedom and Song, my cultural history of modern Irish writing. As it happens, I took the title from Tom Moore's 'Dear Harp of My Country', a highly-charged, sentimental song of hope, which in turn issued from the long period of repression in Ireland before and after the Act of Union in 1801. Not infrequently, as I reflect on history and literature I find myself dwelling on the movement back and forth, on chords, and, then, on the music of all those who share a destiny obscure.

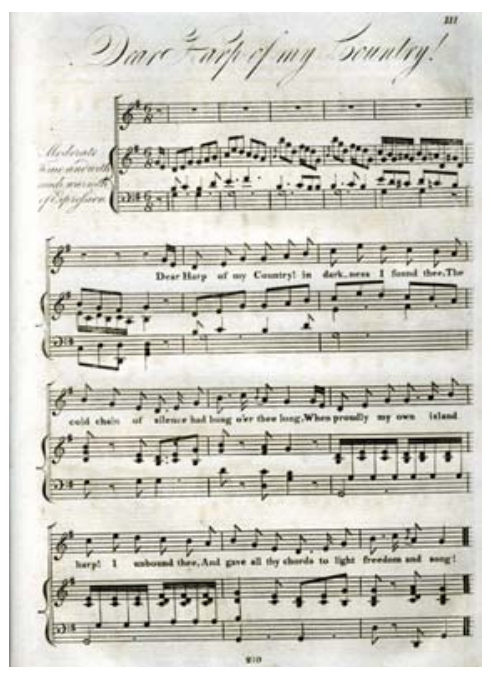

The first stanza of Tom Moore's poignant song about the Irish dark. This image is taken from the sixth number of A Selection of Irish Melodies with Symphonies and Accompaniments by Sir John Stevenson (1815). 
In the summer of 1973 we moved down to the pretty village of Meldreth, south of Cambridge, where, behind a high wall opposite, one of our neighbours, an elderly couple, dressed for candle-lit dinner attended by maids and servants. My partner began teaching at a comprehensive school in Letchworth and I found some part-time teaching at a language school in Cambridge. At the same time I continued reading in Cambridge University Library. I pored over material in the Bradshaw collection of Irish ballads, all the time trying to discern how they might be incorporated into my research on Irish writing. My interest in the oral tradition stemmed from an apprenticeship in my grandmother's cottage in Caherbarna, and I knew at some stage all that knowledge would pay off and I would find a way of bringing it back into my life. When I read Bob Dylan's autobiography Chronicles (2004), the sentence that leaps out at me is 'Folk songs were the underground story'. The 'invisible republic' is how Greil Marcus describes Dylan's lifelong quest, a phrase quoted with approval by the singer. I was reminded of the proximity of the adjectives 'underground' and 'invisible' to some of the guiding principles which inform my own memoir.

I could have done something with such insights if they had been available to me, for I too had been involved in a similar search or driven by the same belief. But it took me years and my Yale cultural history before I hit upon the Irish dark as an overriding theme governing modern Irish writing. The early 1970s was also a period when, in search of the absent, Irish Turgenev and of voices like Miguel Hernández, European writers who impressed me as having an integral connection with the people or whose sympathies were particularly engaged by their continuing plight, I read the work of the political activist Peadar O'Donnell and Liam O'Flaherty, the 'elemental' novelist from the Aran Islands, whose short stories I particularly admired at that time. However, nothing would distract me from the more ambitious task, encouraged by my tutor, of providing a reading of modern Irish writing as a whole.

\section{Works Cited}

Brenan, Gerald. 1962 (1943). The Spanish Labyrinth: The Social and Political Background of the Spanish Civil War. Cambridge: Cambridge University Press.

Campbell, Thomas. 1799. The Pleasures of Hope; With other Poems. Edinburgh: Mundell.

Dylan, Bob. 2004. Chronicles Volume One. London: Simon \& Schuster.

Höhne, Horst. 1983. Ein Ding von Schönheit ist ein Glück auf immer: Gedichte der englischen und schottischen Romantik. Leipzig: Reclam.

Jara, Victor. 1974. Manifiesto: Chile September 1973. Transatlantic Records.

Joyce, James. 1964 (1939). Finnegans Wake. London: Faber and Faber.

Keats, John. 2003. The Complete Poems (ed John Barnard). London: Penguin Classics.

Leavis, F.R.. 1948. The Great Tradition: George Eliot, Henry James, Joseph Conrad. London: Chatto and Windus.

Lewis, George Cornewall. 1836. On Local Disturbances in Ireland: and On the Irish Church Question. London: B. Fellowes.

Moore, Thomas. 1815. A Selection of Irish Melodies with Symphonies and Accompaniments by Sir John Stevenson, $6^{\text {th }}$ Number. London and Dublin: J. Power's.

Pierce, David. 2005. Light, Freedom and Song: A Cultural History of Modern Irish Writing. London and New Haven: Yale University Press.

Stoddard, John L. 1902. John L. Stoddard's Lectures: Supplementary Volume. Boston: Balch Brothers.

Williams, Raymond. 1970. The English Novel from Dickens to Lawrence. London: Chatto and Windus.

Yeats, William Butler. 2000. Selected Poems (ed Timothy Webb). London: Penguin Modern Classics.

Received 16 July 2011 Last version 26 November 2011 